ORIGINAL ARTICLE

\title{
Depression Level Difference Between Gifted and Non-gifted Medical Students
}

\author{
Firas Farisi Alkaff ${ }^{*}$, Adila Taufik Syamlan', Michael Jonatan', Ricardo Adrian \\ Nugraha $^{1}$, Tan Nicko Octora ${ }^{1}$, Azimatul Karimah ${ }^{2}$
}

${ }^{1}$ Faculty of Medicine, Universitas Airlangga, Surabaya, Indonesia

${ }^{2}$ Department of Psychiatry, Faculty of Medicine, Universitas Airlangga, Surabaya, Indonesia - Dr. Soetomo General Hospital, Indonesia

\begin{tabular}{l} 
A R T I C L E I N F O \\
\hline Article history: \\
Received 17 September 2018 \\
Received in revised form 9 \\
November 2018 \\
Accepted 13 November 2018 \\
Available online 30 November \\
2018
\end{tabular}

Keywords:

Beck Depression Inventory,

Depression,

Gifted Students,

Medical Students,

Academic Acceleration.

*) Corresponding author:

firasfarisialkaff@gmail.com

\begin{abstract}
A B S T RA C T
Introduction: The prevalence of depression in medical students are higher than general population and influenced by several risk factors, including being a gifted student. The aim of this study was to find out the difference in depression level between gifted and nongifted medical students.

Methods: This study was a descriptive cross-sectional study in third-year medical students of Universitas Airlangga. Samples from gifted student group was obtained using total sampling method, and equated number for non-gifted group. Depression was measured by using Beck Depression Inventory (BDI).

Results: 34 students, 17 in each group, were participated. 2 gifted medical students and 1 non-gifted medical student were in the mild category, and 1 gifted medical student was in the borderline category. The highest BDI score 17 was in non-gifted medical students. There was no significant difference of the BDI score and category between groups ( $\mathrm{p}=$ 0.154 ; 0.951, respectively).

Conclution: There was no significant difference of depression level between gifted and non-gifted medical students. However, non-gifted medical students have higher mean BDI scores.
\end{abstract}

\section{Introduction}

Depression is a common mental health problem in the world that can occur in various age groups. It is characterized by sadness, loss of interest or pleasure, feelings of guilt or low self-worth, disturbed sleep or appetite, feelings of tiredness, and poor concentration. In its most severe form, depression can lead to suicide, and increased risk of mortality. ${ }^{1}$ Report from WHO showed that depression is the $4^{\text {th }}$ leading cause of disability worldwide, ${ }^{2}$ and predicted to be the second leading in global disease burden by $2020 .^{3}$

There has been an increase in total estimated number of people living with depression by $18.4 \%$ from 2005 to $2015 .{ }^{4}$ In 2015,322 million people in the world live with depression, which represent around $4 \%$ of total population. The highest prevalence region of depression is in South East Asia Region, which accounts for $27 \%$ (around 86 million people). In Indonesia, the prevalence of depression is $3.7 \%$ from total population. The trends of depression incidence is increasing according to age groups, from $7.5 \%$ in $15-19$ years old to $13.5 \%$ in $60-64$ years old group. ${ }^{5}$

It has been revealed that medical students also experience high rates of depression. Systematics review in 2006 on 40 articles revealed that levels of overall psychological distress in medical students is consistently higher than in general population.. ${ }^{6}$ Recent meta-analysis study showed that the prevalence of depression in medical students is 2.2 to 5.2 times than general population in the same age groups. ${ }^{7}$ Several risk factors that might contribute to the higher rate of depression are academic requirements, time pressure, social adjustment, heavy workload, pressure of a clinical environment, and

Biomolecular and Health Science Journal

Available at https://e-journal.unair.ac.id/BHSJ ; DOI: 10.20473/bhsj.v1i2.9716 
the medical curriculum. ${ }^{8,9}$ Apart from that, being a gifted student also become a risk factor in depression. ${ }^{10}$

Throughout history, many gifted and talented people have suffered from various forms of clinical depression. It is because their developmental asynchrony put them at risk for social isolation or misunderstanding; inappropriate educational response; and emotional, intellectual, or social void. This lack of meaningful, positive social interaction is the most important variable in the etiology of depressive disorder for the gifted student. ${ }^{10}$

Until now, no study has been published regarding the depression of the gifted students that enroll in the medical degree. The aim of this study was to find out the difference in the level of depression between gifted and non-gifted medical students.

\section{Methods}

This study was a descriptive cross-sectional study, conducted from October to December 2016. Subjects were third year medical students in Universitas Airlangga. There were 2 groups in this study, gifted students' group and non-gifted students' group. Samples from gifted students' group was obtained using total sampling method, while number of samples from nongifted students' group was equated using 1:1 ratio. The inclusion criteria for the gifted students' group was students with academic acceleration background in high school (either junior high school, senior high school, or both) and aged at least 18 years old. Inclusion criteria for the non-gifted students' group was students without academic acceleration background in high school (both junior and senior high school) and aged 18 years old. Exclusion criteria for both groups were students with history of mental illness or diagnosed with mental illness using PPDGJ-III guideline. Depression was measured using Beck Depression Inventory (BDI). BDI measurement was based on the exact score and based on the categories. The categories were as follows: normal (0-10), mild (11-16), borderline (17-20), moderate (21$30)$, severe (31-40), and extreme (>40). ${ }^{11}$

This study followed the principles of the Declaration of Helsinki. All subjects gave their informed consent prior to their inclusion in the study. Before signed the informed consent, information for informed consent were given. Details that might disclose the identity of the subjects under study were omitted.

Data was analyzed using SPSS version 16.0 (SPSS Inc., Chicago, Ill., USA). Normality of data distribution was analyzed using Shappiro-Wilk Test. Mann-Whitney test was used to determine the significant difference of BDI result between both groups. $\mathrm{P}$ value of $<0.05$ was considered significant.

\section{Results}

A total of 34 students (17 students in each group) were participated. Based on the gender, there were 7 males ( 3 gifted and 4 non-gifted students) and 27 females (14 gifted students and 13 non-gifted students). Based on the academic acceleration background, 1 student underwent acceleration program during junior high school, 12 students during high school, and 4 students during junior and senior high school (table 1).

Table 1. Characteristic of the Subjects

\begin{tabular}{lcccc}
\hline & Gifted-Students & \multicolumn{2}{c}{$\begin{array}{c}\text { Non-Gifted } \\
\text { Students }\end{array}$} \\
\hline Gender & $\mathrm{n}$ & $(\%)$ & $\mathrm{n}$ & $(\%)$ \\
\hline Male & 3 & 17.65 & 4 & 23.5 \\
\hline Female & 14 & 82.35 & 13 & 76.5 \\
\hline $\begin{array}{l}\text { Acceleration } \\
\text { Background }\end{array}$ & & & & \\
\hline No background & 0 & 0 & 17 & 100 \\
\hline $\begin{array}{l}\text { Junior High } \\
\text { School }\end{array}$ & 1 & 5.9 & 0 & 0 \\
\hline $\begin{array}{l}\text { Senior High } \\
\text { School }\end{array}$ & 12 & 70.6 & 0 & 0 \\
\hline $\begin{array}{l}\text { Junior and Senior } \\
\text { High School }\end{array}$ & 4 & 23.5 & 0 & 0 \\
\hline
\end{tabular}

\section{Depression score}

The highest BDI score in gifted-students group were 14, while in non-gifted-students group were 17. Mean BDI score in gifted-students group were $4.29 \pm 4.593$, while in non-gifted students group were $6.18 \pm 4.915$. Based on the BDI category, 15 students in each group were in normal category, 2 gifted students and 1 non-gifted student were in mild category, and only 1 gifted student was in borderline category (table 2).

Table 2. BDI Score Results

\begin{tabular}{lll}
\hline & $\begin{array}{l}\text { Gifted-Students } \\
\text { Group }\end{array}$ & $\begin{array}{l}\text { Non-Gifted } \\
\text { Students Group }\end{array}$ \\
\hline $\begin{array}{l}\text { Highest BDI } \\
\text { Score }\end{array}$ & 14 & 17 \\
\hline Mean BDI Score & $4.29 \pm 4.593$ & $6.18 \pm 4.915$ \\
\hline $\begin{array}{l}\text { BDI Score } \\
\text { Category }\end{array}$ & \\
\hline Normal & 15 & 15 \\
\hline Mild & 2 & 1 \\
\hline Borderline & 0 & 1 \\
\hline Moderate & 0 & 0 \\
\hline Severe & 0 & 0 \\
\hline Extreme & 0 & 0 \\
\hline
\end{tabular}

According to Shappiro Wilk test, the BDI score was not normally distributed. Using Mann Whitney test, it was obtained that the BDI score between groups were not significantly different $(\mathrm{p}=0.154)$. It was also obtained using Mann Whitney test that there was no significant difference in BDI category between groups ( $p$ $=0.951)($ table 3$)$. 
Table 3. Mann Whitney U test

\begin{tabular}{llll}
\hline & $\begin{array}{l}\text { Mean Rank } \\
\text { Gifted } \\
\text { Students } \\
\text { Group }\end{array}$ & $\begin{array}{l}\text { Mean Rank } \\
\text { Non-Gifted } \\
\text { Students } \\
\text { Group }\end{array}$ & \\
& 15.09 & 19.91 & 0.154 \\
\hline BDI Score & 17.44 & 17.56 & 0.951 \\
\hline BDI & & & \\
Category & &
\end{tabular}

\section{Discussion}

In this study, the prevalence of depression in third year medical students was $11.76 \%$. Compared to the data from WHO which showed that prevalence of depression in Indonesian people was $3.7 \%, 5$ it appears that the depression in medical students is very high. Previous study in India using BDI as a measurement on $1^{\text {st }}$ to $4^{\text {th }}$ year medical students showed that the overall prevalence of depression was $71.25 \%$, with $80 \%$ of them in mild and moderate category of depression. ${ }^{12}$ Recent systematic review and meta-analysis showed that the prevalence of depression or depressive symptoms in medical students was $27.2 \% .^{7}$

Academic requirements, time pressure, social adjustment, heavy workload, pressure of a clinical environment, and the medical curriculum are several factors that contribute to the high prevalence of depression in medical students. ${ }^{8,}{ }^{9}$ Dyrbye et al. in their study of burnout among medical students, residents, and early physicians in United States explain that the symptoms of depression were most prevalent during medical school and were less prevalent during residency and the early career stages. ${ }^{13}$ Preclinical students more likely to endorse that depressed medical students would provide inferior care to their patients, are unable to cope with medical school stress, and are less intelligent than their peers. ${ }^{14}$

In this study, there was no significant difference of depression level between gifted and non-gifted medical students. In contrary, recent study in USA showed that the risk of developing depressive disorder is 3.85 times higher in high intelligence people compare to national average..$^{15}$ The difference in the finding might be because in developed country, people were more open to their mental health condition than in the developing country.

Previous study which analyzed the strategy used by gifted students to cope with stress suggested that both gifted and non-gifted students experienced similar stressors and coping responses. The difference between them were in anger coping, humor, and problem-solving approaches. ${ }^{16}$ Gifted students with high level of intelligence can move at an extremely fast pace through the prescribed curriculum. They tend to be multitalented; the extraordinary superiority of extremely gifted children across a wide range of subject fields is well documented. ${ }^{17}$ One might argue that several contributing factors to the depression would not be an issue for gifted students. In contrary, another study suggested that gifted students could hide their depression. A critical mass of anecdotal evidence in the form of clinical reports, reports from parents, and reports of depression survivors themselves attest to the fact that some gifted teens experience depression and that they are capable of disguising even the most severe symptoms. ${ }^{10}$

Problems that might be difficult for the gifted medical students to deal with when they are in the clinical years. In that years of study, they will have to make a direct interaction with the patients. Moreover, they also have to interact with their friends and teacher for the discussion. However, as explained above, social interaction is one of the contributing factors for the depression on the gifted students. Gifted students are often unaware of how different their thoughts and feelings are from even their less-gifted peers. If they were unable to experience meaningful spiritual, emotional, and intellectual exchange in social and educational environments, they are more susceptible to a depressive state than those who had more positive experiences. ${ }^{10}$

However, this study has several limitations. The samples of the study were too small even when the total sampling for the non-gifted students group was used. The ratio between gifted and non-gifted students group should be increased by $1: 2$ or $1: 3$. Samples should be also from the clinical years in order to analyze the effect of the social interaction. There is no relevant study published regarding the level of depression between gifted and non-gifted medical students. Therefore, it is impossible to analyze and compare the findings between studies.

\section{Conclusion}

There was no significant difference of depression level between gifted and non-gifted medical students.

However, non-gifted medical students have higher mean BDI scores, as mental issue has many multifactorial contributed.

\section{Conflict of Interest}

The author stated there is no conflict of interest

\section{References}

1. Lim GY, Tam WW, Lu Y, Ho CS, Zhang MW and Ho RC. Prevalence of Depression in the Community from 30 Countries between 1994 and 2014. Scientific Reports. 2018; 8: 2861.

2. Murray CJ and Lopez AD. Evidence-Based Health Policy-Lessons from The Global Burden of Disease Study. Science. 1996; 274: 740-3.

3. World Health Organization. The World Health Report : 2001 : Mental health : New Understanding, New Hope. Geneva: World Health Organization, 2001. 
4. GBD 2015 Disease and Injury Incidence and Prevalence Collaborators. Global, Regional, and National Incidence, Prevalence, and Years Lived with Disability for 310 Diseases and Injuries, 1990-2015: A Systematic Analysis for The Global Burden of Disease Study 2015. Lancet. 2016; 388: 1545-602.

5. World Health Organization. Depression and Other Common Mental Disorders: Global Health Estimates. Geneva: World Health Organization, 2017.

6. Dyrbye LN, Thomas MR and Shanafelt TD. Systematic Review of Depression, Anxiety, and Other Indicators of Psychological Distress Among U.S. and Canadian Medical Students. Academic medicine : journal of the Association of American Medical Colleges. 2006; 81: 354-73.

7. Rotenstein LS, Ramos MA, Torre M, et al. Prevalence of Depression, Depressive Symptoms, and Suicidal Ideation Among Medical Students: A Systematic Review and MetaAnalysis. Jama. 2016; 316: 2214-36.

8. Moir F, Yielder J, Sanson J and Chen Y. Depression in Medical Students: Current Insights. Advances in medical education and practice. 2018; 9: 323-33.

9. Sreeramareddy CT, Shankar PR, Binu VS, Mukhopadhyay C, Ray B and Menezes RG. Psychological Morbidity, Sources of Stress and Coping Strategies among Undergraduate Medical Students of Nepal. BMC medical education. 2007; 7: 26.

10. Jackson S and Peterson J. Depressive Disorder in Highly Gifted Adolescents. The Journal of Secondary Education. 2003; 14: 175-86.

11. Beck AT, Ward CH, Mendelson M, Mock J and Erbaugh J. An Inventory for Measuring Depression. Archives of General Psychiatry. 1961; 4: 561-71.

12. Kumar G, Jain A and Hegde S. Prevalence of Depression and Its Associated Factors Using Beck Depression Inventory among Students of a Medical College in Karnataka. Indian Journal of Psychiatry. 2012; 54: 223-6.

13. Dyrbye LN, West CP, Satele D, et al. Burnout among U.S. Medical Students, Residents, and Early Career Physicians Relative to the General U.S. Population. Academic medicine : journal of the Association of American Medical Colleges. 2014; 89: 443-51.

14. Schwenk TL, Davis L and Wimsatt LA. Depression, Stigma, and Suicidal Ideation in Medical Students. Jama. 2010; 304: 1181-90.

15. Karpinski RI, Kolb AMK, Tetreault NA and Borowski TB. High Intelligence: A Risk Factor for Psychological and Physiological Overexcitabilities. Intelligence. 2018; 66: 823.

16. Shaunessy E and Suldo SM. Strategies Used by Intellectually Gifted Students to Cope With Stress During Their Participation in a High School International Baccalaureate Program. Gifted Child Quarterly. 2010; 54: 127-37.

17. Gross MUM. Issues in the Cognitive Development of Exceptionally and Profoundly Gifted Individuals. In: Heller KA, Monks FJ, Sternberg RJ and Subotnik RF, (eds.). International handbook of giftedness and talent. Oxford: Pergamon Press, 2000, p. 179-92. 